realization of pedagogical conditions of professional self-improvement of future law enforcement specialists is determined. It is stated that the future law enforcement specialist should become a moral standard of a young person, an example of citizenship, tolerance and high spirituality.

The analysis of scientific and pedagogical sources shows a number of factors that cause the need to make significant changes in the training of the modern law enforcement specialists to the professional activity.

As a result of the research, pedagogical conditions are determined as the circumstances on which the effectiveness of the functioning of the system of formation of law enforcement specialists' readiness to the professional self-improvement depends. That is, the effectiveness and efficiency of the professional activity of law enforcement specialists depends to a large extent on the activation of the professional self-improvement of future specialists during training.

It is stated that optimization of the process of forming the readiness of future law enforcement specialists to the professional self-improvement promotes introduction of proper pedagogical conditions, among which the researchers name: creation of social and psychological environment, development of motivation to the professional self-improvement, pedagogical guidance of professional self-improvement taking into account the individual and psychological individual's characteristics, self-development, etc.

The following pedagogical conditions of the professional self-improvement of future law enforcement specialists are substantiated: ensuring positive motivation and need for professional self-improvement of future law enforcement specialists; constructing the content of educational material that guides future law enforcement specialists to self-improvement; creation of developmental, educational, social and psychological space with the use of modern innovative technologies; an integrative approach to organization and practice.

Key words professional self-improvement, future specialists, law enforcement bodies, educational process, pedagogical conditions, self-development, motivation, optimization of professional training.

удк 378:81'233+007-047.22]364-43

Людмила Березовська

«ДВНЗ Прикарпатський національний університет

імені Василя Стефаника»

ORCID ID 0000-0002-3032-7261

DOI 10.24139/2312-5993/2019.07/162-172

\title{
РІВНІ СФОРМОВАНОСТІ КОМУНІКАТИВНО-МОВЛЕННЄВОЇ КОМПЕТЕНТНОСТІ МАЙБУТНІХ СОЦІАЛЬНИХ ПРАЦІВНИКІВ У ПРОЦЕСІ ФАХОВОї ПІДГОТОВКИ
}

У статті здійснено аналіз рівнів сформованості комунікативно-мовленнєвої компетентності майбутніх соціальних працівників у процесі фахової підготовки. Визначено діагностичний інструментарій, критерії, показники та рівні комунікативно-мовленнєвої компетентності майбутніх соціальних працівників.

Одержані в ході експерименту результати свідчать, що студенти експериментальної і контрольної груп виявляють у більшості задовільний і низький рівні сформованості комунікативно-мовленнєвої компетентності, що не відповідає вимогам фрахової підготовки майбутніх соціальних працівників і потребує цілеспрямованої роботи під час формувального етапу експерименту з метою підвищення рівнів професійної, комунікативно-мовленнєвої компетентності в закладах вищої освіти. 
Ключові слова: рівні срормованості, комунікативно-мовленнєва компетентність, показники, критерії, майбутні соціальні працівники.

Постановка проблеми. Соціально-економічні та політичні зміни, що відбуваються в Україні, ставлять нові вимоги перед системою вищої освіти, зокрема, адаптації освітнього процесу до потреб та запитів суспільства; підготовку фахівця нового типу, здатного до оперативного та продуктивного вирішення складних професійних завдань. Ефективність підготовки фахівця майбутнього соціального працівника залежить від багатьох чинників, зокрема від рівня сформованості комунікативно-мовленнєвої компетентності як складової професійного становлення соціального працівника.

Аналіз актуальних досліджень. У наукових працях учених висвітлено такі аспекти цієї проблеми: шляхи підвищення рівня професійної підготовки соціальних працівників (С. Архипова, А. Капська, О. Карпенко, Л. Міщик, В. Поліщук, В. Сидоров, Є. Холостова та ін.); теоретичні положення розгляду комунікативної компетентності майбутніх соціальних працівників (В. Березан, Д. Годлевської, О. Канюк І. Козубовської, М. Лаптєвої, О. Пасічник та ін.).

Незважаючи на наявність численних досліджень, присвячених комунікативній компетентності, вважаємо, що проблема формування комунікативно-мовленнєвої компетентності майбутніх соціальних працівників у закладах вищої освіти недостатньо висвітлена.

Метою статті $€$ характеристика рівнів сформованості комунікативномовленнєвої компетентності студентів - майбутніх соціальних працівників у процесі професійної підготовки в закладах вищої освіти.

Методи дослідження. Для оцінювання рівнів сформованості комунікативно-мовленнєвої компетентності студентів - майбутніх соціальних працівників до здійснення професійної, комунікативно-мовленнєвої діяльності було використано: анкетування 3 метою визначення стану обізнаності студентів 3 поняттями «комунікація», «спілкування», «комунікативно-мовленнєва діяльність»; тестові завдання на визначення вміння характеризувати понятя, які визначають зміст комунікативномовленнєвої компетентності; картки із завданнями на виявлення обізнаності студентів із діяльністю соціального працівника; питальник Форвергера на контактність; методика КOC-1 для визначення рівнів сформованості комунікативно-мовленнєвої компетентності у спілкуванні з партнером; тест «Вибір стратегій у конфліктних ситуаціях» за К. Томасом; питальник «Оцінка комунікабельності в авторській розробці»; вправи, рольові ігри, розгляд професійно-спрямованих проблемних ситуацій.

Виклад основного матеріалу. Аналіз науково-методичної літератури засвідчив різні підходи науковців щодо визначення структури оцінювання тих чи інших умінь студентів. 
Так, учені (Ю. Лега, В. Мельник, І. Цимбалюк) пропонують оцінювати компетентність фахівця із визначенням коефіцієнта ефективності за різними видами діяльності (Лега, 2003).

Т. Браже вважає, що процедуру оцінювання потрібно здійснювати «на виході» за результатами цілеспрямованої професійної підготовки та за умови виконання фахівцем практико-зорієнтованого проекту (Браже, 1995, с. 65).

Виходячи з того, що показником якості підготовки майбутніх соціальних працівників до роботи з клієнтами визначено професійну, комунікативно-мовленнєву компетентність, структурними компонентами якої $€$ теоретичні знання, комунікативно-мовленнєві вміння та практичні навички було виокремлено критерії та показники комунікативномовленнєвої компетентності майбутніх соціальних працівників.

3 метою визначення критеріїв та показників сформованості комунікативно-мовленнєвої компетентності у процесі професійної підготовки майбутніх соціальних працівників, доцільно визначити співвідношення понять «критерій»та «показник».

Термін «критерій» - (від грец. - кriterion) - судження, переконання, мірило) - це мірило для визначення оцінки предмета чи явища; ознака, взята за основу класифікацій (Розенталь та Юдина, 1968, с. 196); підстава для оцінки, визначення або класифікації чогось (Бусел, 2005, с. 588).

Таким чином, критерій - це набір ознак досліджуваних властивостей предмета, на основі яких визначається рівень сформованості комунікативно-мовленнєвої компетентності соціальних працівників у процесі фахової підготовки. Критерії розкриваються через показники, які його характеризують. Один критерій може мати декілька показників. Показник - це те, за допомогою чого можна судити про розвиток та хід чого-небудь (Ожегов, 1986, с. 1369).

у контексті дослідження критеріями комунікативно-мовленнєвої компетентності студентів - майбутніх соціальних працівників нами визначено (рис. 1).

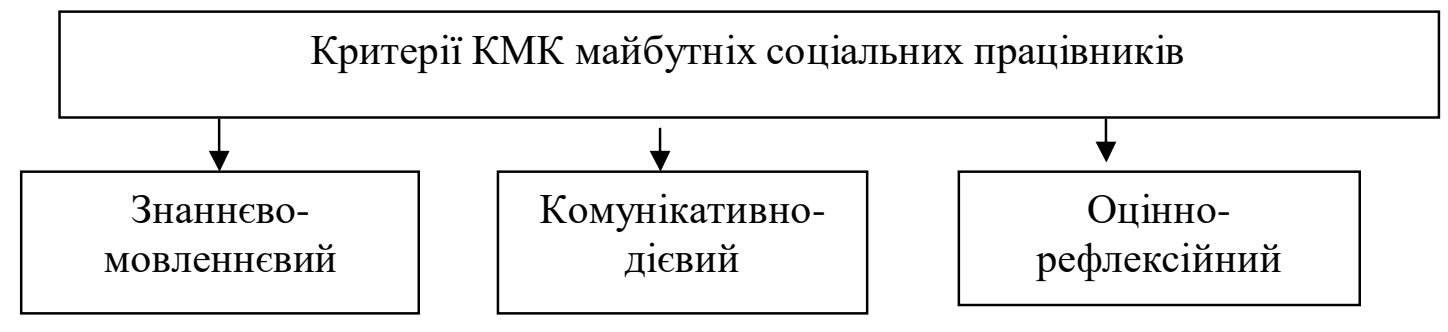

Рис. 1. Критерії КМК майбутніх соціальних працівників

Знаннєво-мовленнєвий критерій - обізнаність студентів із професійною діяльністю соціального працівника, цінностями комунікативно-мовленнєвої компетентності в майбутній професійній 
діяльності, володіння професійною лексикою, засвоєнні норм літературної мови, спрямованістю на саморозвиток, самоосвіту та самовдосконалення.

Комунікативно-дієвий - характеризується вмінням установлювати міжособистісні взаємини з учасниками комунікативного процесу, розвитком комунікативних здібностей, умінням легко та невимушено вести діалог, користуватися вербальними та невербальними засобами спілкування, конструктивно розв'язувати конфліктні ситуації, визначати причини непорозумінь, проявляти комунікативну толерантність, емпатію, дотримуватися правил мовленнєвого етикету.

Оцінно-рефлексійний - наявність уміння об'єктивно оцінювати себе, виявляти професійні переваги та недоліки, корегувати їх, здійснювати взаємо- та самоаналіз комунікативно-мовленнєвих дій у спілкуванні 3 партнером, порівнювати, узагальнювати, підвищувати рівень професійної майстерності.

Окреслені критерії взаємозв'язані між собою, оскільки для формування комунікативно-мовленнєвої компетентності, студенти майбутні соціальні працівники повинні мати не лише грунтовну теоретичну підготовку, але й сформовані навички професійно-практичної діяльності в межах спеціальності, орієнтацію на міждисциплінарний, інтегрований підхід до навчання, володіти сучасними методами та технологіями, необхідними для самоаналізу, розвитку творчості та підвищення професійної компетентності.

Таким чином, проблема формування комунікативно-мовленнєвої компетентності майбутніх соціальних працівників у закладах вищої освіти має вирішуватися комплексно: і в аспекті розроблення методики формування комунікативно-мовленнєвої компетентності, і в аспекті професійно-практичної підготовки майбутніх соціальних працівників до здійснення професійної діяльності.

До визначений критеріїв було розроблено показники та діагностичний інструментарій на виявлення рівнів сформованості комунікативно-мовленнєвої компетентності майбутніх соціальних працівників у процесі фахової підготовки в закладах вищої освіти.

В експериментальному дослідженні взяли участь студенти 4-х курсів спеціальності 231 «Соціальна робота», першого (бакалаврського) рівня вищої освіти. Сформованість комунікативно-мовленнєвої компетентності визначали за рівнями: високий, достатній, задовільний та низький.

Проаналізуємо рівні сформованості комунікативно-мовленнєвої компетентності майбутніх соціальних працівників за показниками знаннєво-мовленнєвого критерію. Результати подано в таблиці 1. 
Таблиця 1

Рівні сформованості комунікативно-мовленнєвої компетентності майбутніх соціальних працівників за показниками знаннєво-мовленнєвого критерію (у \%) (констатувальний зріз)

\begin{tabular}{|c|c|c|c|c|c|c|}
\hline \multirow{2}{*}{$\begin{array}{l}\text { № } \\
\Pi / \Pi\end{array}$} & \multirow[t]{2}{*}{ Показники } & \multirow{2}{*}{$\begin{array}{l}\text { Гру- } \\
\text { пи }\end{array}$} & \multicolumn{4}{|c|}{ Рівні } \\
\hline & & & Високий & $\begin{array}{c}\text { Достат } \\
\text { ній }\end{array}$ & $\begin{array}{c}\text { Задовіль } \\
\text { ний }\end{array}$ & Низький \\
\hline \multirow[t]{2}{*}{1} & \multirow{2}{*}{$\begin{array}{l}\text { Обізнаність із поняттями: } \\
\text { «комунікація, «спілкування», } \\
\text { «комунікативно-мовленнєва } \\
\text { діяльність» }\end{array}$} & $\mathrm{E \Gamma}$ & 9,7 & 16,4 & 28,7 & 45,2 \\
\hline & & $\mathrm{K} \Gamma$ & 9,1 & 17,2 & 29,8 & 43,9 \\
\hline \multirow[t]{3}{*}{2} & \multirow{3}{*}{$\begin{array}{lr}\text { Усвідомлення } & \text { поняття } \\
\text { «соціальний } & \text { працівник - } \\
\text { суб'єкт } & \text { комунікативно- } \\
\text { мовленнєвої, } & \text { професійної } \\
\text { діяльності» } & \end{array}$} & ЕГ & 8,6 & 10,1 & 24,6 & 56,7 \\
\hline & & & & & & \\
\hline & & $\mathrm{K} \Gamma$ & 8,2 & 10,4 & 23,9 & 57,5 \\
\hline \multirow[t]{2}{*}{3} & \multirow{2}{*}{$\begin{array}{l}\text { Обізнаність із поняттями } \\
\text { «компетенція», } \\
\text { компетентність» }\end{array}$} & $\mathrm{E} \Gamma$ & 10,1 & 17,6 & 31,3 & 41,0 \\
\hline & & $\mathrm{K} \Gamma$ & 10,4 & 17,5 & 31,7 & 40,4 \\
\hline \multirow[t]{3}{*}{4.} & \multirow{3}{*}{$\begin{array}{l}\text { Обізнаність } 3 \text { поняттями } \\
\text { «мовленнєва компетенція», } \\
\text { «комунікативна } \\
\text { компетенція» } \\
\text { «комунікативно-мовленнєва } \\
\text { компетентність» }\end{array}$} & $\mathrm{E} \Gamma$ & 7,3 & 11,3 & 25,2 & 56,2 \\
\hline & & & & & & \\
\hline & & КГ & 7,6 & 10,9 & 25,6 & 55,9 \\
\hline \multirow[t]{2}{*}{5.} & \multirow{2}{*}{$\begin{array}{ll}\text { Обізнаність } 3 & \text { поняттями } \\
\text { «комунікативно- } & \\
\text { мовленнєвий } & \text { супровід» } \\
\text { професійної } & \text { діяльності } \\
\text { соціального працівника }\end{array}$} & ЕГ & 6,2 & 12,4 & 27,7 & 53,7 \\
\hline & & $\mathrm{K} \Gamma$ & 6,4 & 12,1 & 28,3 & 53,2 \\
\hline \multirow{2}{*}{\multicolumn{2}{|c|}{$x$}} & $\mathrm{E} \Gamma$ & 8,38 & 13,56 & 27,5 & 50,56 \\
\hline & & $\mathrm{K} \Gamma$ & 8,34 & 13,62 & 27,86 & 50,18 \\
\hline
\end{tabular}

Представлена в таблиці кількісна характеристика рівнів сформованості комунікативно-мовленнєвої компетентності за результатами кожного з показників знаннєво-мовленнєвого критерію, свідчить, про домінування задовільного (31,3 \% в ЕГ та $31,7 \%$ - КГ) i низького (56,7 \% в ЕГ та 57,5 \% - КГ) рівнів. Високий рівень сформованості комунікативно-мовленнєвої компетентності становив лише $\chi=8,38 \%$ в ЕГ і 8,34\% - КГ. Середньостатистичне значення достатнього рівня становило $13,56 \%$ в ЕГ та $13,62 \%-$ КГ.

Кількісний аналіз кожного з показників знаннєво-мовленнєвого критерію, свідчить, що найвищий відсоток було одержано за показником обізнаності з поняттями «компетенція», «компетентність». Високого рівня розвитку досягли 10,1 \% студентів ЕГ та 10,4 \% - КГ; достатній продемонстрували - 17,6 \% студентів ЕГ та 17,5 \% - КГ, задовільний - 
31,3 \% студентів в ЕГ та 31,7 \% - КГ; низький - 41 \% студентів ЕГ та 40,4 \% КГ. За показником обізнаність з поняттями: «комунікація», «спілкування», «комунікативно-мовленнєва діяльність переважав задовільний рівень $(28,7$ \% в ЕГ та 29,8 \% - у КГ). Низький рівень сформованості комунікативномовленнєвої компетентності домінував за показником усвідомлення поняття «соціальний працівник - суб'єкт комунікативно-мовленнєвої, професійної діяльності» (56,7 \% студентів ЕГ та 57,5\% - у КГ). За показником обізнаність із поняттями «мовленнєва компетенція», «комунікативна компетенція», «комунікативно-мовленнєва компетентність» переважав середній рівень (25,2 \% студентів ЕГ та 25,6 \% КГ). Показник обізнаності 3 поняттями «комунікативно-мовленнєвий супровід» професійної діяльності соціального працівника невисокий: тільки 6,2 \% студентів в ЕГ і 6,4 \% у КГ були на високому рівні.

Якісний аналіз результатів засвідчив, що студенти не є обізнаними 3 поняттями «комунікація», «спілкування», «комунікативно-мовленнєва діяльність», «комунікативно-мовленнєвий супровід», не завжди розуміють та правильно застосовують комунікативно-мовленнєві поняття. Для більшості студентів виявилися проблематичними завдання пов'язані 3 поняття «супровід». Майбутні соціальні працівники не змогли дати визначення поняттю «супровід», назвати види та функції супроводу, навести приклади здійснення комунікативно-мовленнєвого супроводу у професійній діяльності соціального працівника.

Результати виконання завдань за комунікативно-дієвим критерієм представлено в таблиці 2.

Представлена в таблиці 2 кількісна характеристика рівнів сформованості комунікативно-мовленнєвої компетентності майбутніх соціальних працівників за показниками комунікативно-дієвого критерію свідчить про домінування задовільного (36,6 \% в ЕГ та 38,5 \% - у КГ) та низького (45 \% в ЕГ та 45,4 - у КГ) рівнів. Високий рівень становив лише $\chi=$ 7,4 \% - в ЕГ і 7,2 \% - у КГ. Середньостатистичне значення достатнього рівня становило 14,5\% - в ЕГ та $13,9 \%$ - у КГ.

Щодо кількісних результатів кожного з показників за комунікативнодієвим критерієм, то, як свідчить таблиця, найбільший відсоток було одержано за показником уміння доречно використовувати вербальні і невербальні засоби виразності мовлення та формули мовленнєвого етикету (високий рівень: 8,1 \% - в ЕГ та 7,8 \% у - КГ; достатній рівень: 14,5\% - в ЕГ та 14,7 \% - у КГ). За показником уміння організовувати ініціативнодіалогове спілкування високий рівень складав 7,4 \% - в ЕГ та 6,8 \% - у КГ. Проте, переважав низький рівень $(44,5 \%$ - в ЕГ та $43,9 \%$ - у КГ) та задовільний $(36,6$ \% - ЕГ та 38,5 \% - у КГ) рівень. Результати, що були одержані за показником уміння конструктивно розв'язувати конфліктні ситуації, прогнозувати поведінку партнера також засвідчили невисокі 
результати (тільки 6,7 \% студентів були на високому рівні в ЕГ та $7 \%$ - у КГ; достатній рівень в ЕГ становив 17,3 \%, у КГ - 16,6 \%; задовільний - 35,2 \% в ЕГ та 34,8 \% - у КГ; низький рівень переважав в ЕГ - 40,8 \% та в КГ - 41,6 \%).

Таблиця 2

Рівні сформованості комунікативно-мовленнєвої компетентності майбутніх соціальних працівників за показниками комунікативно-дієвого критерію (у \%) (констатувальний зріз)

\begin{tabular}{|c|c|c|c|c|c|c|}
\hline \multirow{2}{*}{$\begin{array}{l}\text { № } \\
\Pi / \Pi\end{array}$} & \multirow[t]{2}{*}{ Показники } & \multirow[t]{2}{*}{ Групи } & \multicolumn{4}{|c|}{ Рівні } \\
\hline & & & Високий & $\begin{array}{c}\text { Достат } \\
\text { ній }\end{array}$ & $\begin{array}{c}\text { Задовіль } \\
\text { ний }\end{array}$ & Низький \\
\hline \multirow[t]{2}{*}{1} & \multirow{2}{*}{$\begin{array}{lr}\text { Уміння } & \text { організовувати } \\
\text { iнiціативно } & \text { діалогове } \\
\text { спілкування з клієнтом }\end{array}$} & $\mathrm{E \Gamma}$ & 7,4 & 11,7 & 36,6 & 44,5 \\
\hline & & КГ & 6,8 & 10,6 & 38,5 & 43,9 \\
\hline \multirow[t]{2}{*}{2} & $\begin{array}{lr}\text { Уміння } & \text { доречно } \\
\text { використовувати } & \text { вербальні } \\
\text { і } & \text { невербальні }\end{array}$ & $\mathrm{E \Gamma}$ & 8,1 & 14,5 & 32,4 & 45,0 \\
\hline & $\begin{array}{l}\text { виразності мовлення та } \\
\text { формули } \\
\text { етикету }\end{array}$ & $\mathrm{K} \Gamma$ & 7,8 & 14,7 & 32,6 & 45,4 \\
\hline \multirow[t]{2}{*}{3} & \multirow{2}{*}{$\begin{array}{lr}\text { Уміння } & \text { конструктивно } \\
\text { розв'язувати } & \text { конфліктні } \\
\text { ситуації, } & \text { прогнозувати } \\
\text { поведінку партнера }\end{array}$} & $\mathrm{E \Gamma}$ & 6,7 & 17,3 & 35,2 & 40,8 \\
\hline & & $\mathrm{K \Gamma}$ & 7,0 & 16,6 & 34,8 & 41,6 \\
\hline \multirow{2}{*}{\multicolumn{2}{|c|}{$\chi$}} & $\mathrm{E} \Gamma$ & 7,4 & 14,5 & 34,7 & 43,4 \\
\hline & & КГ & 7,2 & 13,9 & 35,3 & 43,6 \\
\hline
\end{tabular}

Якісний аналіз результатів засвідчив, що у студентів відсутні відповідні знання з організації ініціативно-діалогового спілкування, вони не дотримуються правил ведення діалогу, не використовують формули мовленнєвого етикету у професійно-діловому спілкуванні, відчувають труднощі, моделюючи діалог відповідно до поставлених завдань, не вміють конструктивно вирішувати конфліктні ситуації.

Результати виконання завдань за оцінно-рефлексійним критерієм представлено таблиці 3.

Щодо кількісних результатів кожного з показників за оціннорефлексійним критерієм, то як свідчать дані, наведені в таблиці 3, найбільший відсоток було одержано за показником уміння адекватно оцінювати комунікативно-мовленнєву діяльність майбутніх соціальних працівників (високий рівень: 8,6 \% - в ЕГ та 7,7\% - у КГ). Середньоарифметичне значення високого рівня дорівнювало 7,2 \% студентів в ЕГ та 6,4 \% - у КГ. Як бачимо, більшість студентів перебували на задовільному $\chi=38,4 \%$ студентів ЕГ та $\chi=39,3 \%$ у КГ та низькому $\chi=38 \%$ студентів ЕГ та $\chi=38,7 \%$ - у КГ. Результати, що були одержані за 
показником уміння здійснювати самоаналіз своїх комунікативномовленнєвих дій у спілкуванні з партнером, виявилися найнижчими (тільки 5,1 \% студентів були на високому рівні в ЕГ та 4,3 \% - у КГ; достатній рівень в ЕГ становив 11,5\%, у КГ - 10,4 \%; задовільний рівень складав 37,2 \% - в ЕГ та 38,5 \% - у КГ. Домінував низький рівень (42,7 \% в ЕГ та 47,2 \% в КГ). За показником уміння ефективної мовленнєвої самопрезентації «Я соціальний працівник» (самооцінка) високий рівень в ЕГ складав 7,9 \% в ЕГ та 7,2 \% у КГ; достатній рівень засвідчили в ЕГ- 14,2 \% студентів, у КГ - 13,6 \%. При цьому, переважав низький $(44,6 \%$ - в ЕГ та $44,1 \%$ - у КГ) та достатній $(35,4 \%$ - в ЕГ та $34,8 \%$ - у Кг) рівні.

Таблиця 3

Рівні сформованості комунікативно-мовленнєвої компетентності майбутніх соціальних працівників за показниками оцінно-рефлексійного критерію (у \%) (констатувальний зріз)

\begin{tabular}{|c|c|c|c|c|c|c|}
\hline \multirow{2}{*}{$\begin{array}{l}\text { № } \\
\Pi / \Pi\end{array}$} & \multirow[t]{2}{*}{ Показники } & \multirow{2}{*}{$\begin{array}{c}\text { Гру- } \\
\text { пи }\end{array}$} & \multicolumn{4}{|c|}{ Рівні } \\
\hline & & & Високий & Достатній & $\begin{array}{c}\text { Задовіль- } \\
\text { ний }\end{array}$ & $\begin{array}{c}\text { Низь- } \\
\text { кий }\end{array}$ \\
\hline \multirow[t]{3}{*}{1} & \multirow{3}{*}{$\begin{array}{lr}\text { Уміння } & \text { здійснювати } \\
\text { самоаналіз } & \text { своїх } \\
\text { комунікативно-мовленнєвих } \\
\text { дій у у спілкуванні } \\
\text { партнером }\end{array}$} & $\mathrm{E} \Gamma$ & 5,1 & 11,5 & 37,2 & 42,7 \\
\hline & & & & & & \\
\hline & & КГ & 4,3 & 10,4 & 38,5 & 47,2 \\
\hline \multirow[t]{2}{*}{2} & \multirow{2}{*}{$\begin{array}{lc}\text { Уміння } & \text { ефективної } \\
\text { мовленнєвої } & \\
\text { самопрезентації } & \text { «Я } \\
\text { соціальний } & \text { працівник» } \\
\text { (самооцінка) } & \end{array}$} & ЕГ & 7,9 & 14,2 & 35,4 & 44,6 \\
\hline & & КГ & 7,2 & 13,6 & 34,8 & 44,1 \\
\hline \multirow[t]{2}{*}{3} & $\begin{array}{l}\text { Уміння адекватно оцінювати } \\
\text { комунікативно-мовленнєву }\end{array}$ & ЕГ & 8,6 & 23,6 & 42,5 & 26,8 \\
\hline & $\begin{array}{lr}\text { діяльність } & \text { майбутніх } \\
\text { соціальних } & \text { працівників } \\
\text { (взаємооцінка) } & \end{array}$ & $\mathrm{K} \Gamma$ & 7,7 & 22,8 & 44,6 & 24,9 \\
\hline \multirow{2}{*}{\multicolumn{2}{|c|}{$\chi$}} & ЕГ & 7,2 & 16,4 & 38,4 & 38 \\
\hline & & $\mathrm{K} \Gamma$ & 6,4 & 15,6 & 39,3 & 38,7 \\
\hline
\end{tabular}

Якісний аналіз результатів сформованості комунікативномовленнєвої компетентності за оцінно-рефлексійним критерієм засвідчив, що у студентів відсутні відповідні професійні знання, щодо ефективного здійснювання самоаналізу своїх комунікативно-мовленнєвих дій у спілкуванні з партнером, не в повному обсязі характеризують особливості професійної діяльності соціального працівника.

Загальні кількісні результати сформованості рівнів комунікативномовленнєвої компетентності майбутніх соціальних працівників подано в таблиці 4. 
Табличя 4

Сформованість рівнів комунікативно-мовленнєвої компетентності майбутніх соціальних працівників у процесі професійної підготовки (констатувальний етап \%)

\begin{tabular}{|c|c|c|c|c|c|}
\hline \multirow[b]{2}{*}{ Критерії } & \multirow[b]{2}{*}{ 站 } & \multicolumn{4}{|c|}{ Рівні \% } \\
\hline & & 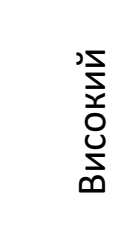 & 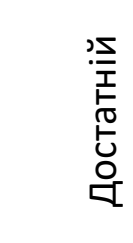 & 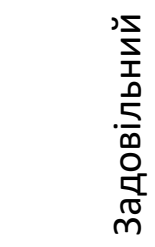 & 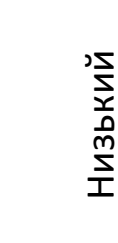 \\
\hline \multirow{2}{*}{$\begin{array}{l}\text { Знаннєво- } \\
\text { мовленнєвий }\end{array}$} & $\mathrm{E \Gamma}$ & 8,38 & 13,56 & 27,5 & 50,56 \\
\hline & KГ & 8,34 & 13,62 & 27,86 & 50.18 \\
\hline \multirow[t]{2}{*}{ Комунікативно-дієвий } & $\mathrm{E \Gamma}$ & 7,4 & 14,5 & 34,7 & 43,4 \\
\hline & KГ & 7,2 & 13,9 & 35,3 & 43,6 \\
\hline \multirow[t]{2}{*}{ Оцінно-рефлексійний } & $\mathrm{E \Gamma}$ & 7,2 & 16,4 & 38,4 & 38 \\
\hline & $\mathrm{K \Gamma}$ & 6,4 & 15,6 & 39,3 & 38,7 \\
\hline \multirow{2}{*}{$\chi$} & $\mathrm{E} \Gamma$ & 7,6 & 15 & 33,5 & 43,9 \\
\hline & $\mathrm{K} \Gamma$ & 7,3 & 14,3 & 34,2 & 44,2 \\
\hline
\end{tabular}

Із представлених у таблиці 4 даних бачимо, що високий рівень комунікативно-мовленнєвої компетентності майбутніх соціальних працівників було виявлено лише у 7,6 \% студентів ЕГ та 7,3 \% - КГ. Середньоарифметичне значення достатнього рівня дорівнювало $15 \%$ студентів ЕГ та 14,3 \% - у КГ. Задовільний рівень було виявлено у $33,5 \%$ студентів ЕГ та 34,2 \% - КГ. Переважна більшість студентів засвідчили низький рівень сформованості комунікативно-мовленнєвої компетентності (43,9 \% студентів ЕГ та 44,2 \% - Кг).

Висновки та перспективи подальших наукових розвідок. Одержані в ході констатувального етапу експерименту результати свідчать, що студенти експериментальної і контрольної груп виявляють у більшості задовільний і низький рівні сформованості комунікативно-мовленнєвої компетентності, що не відповідає вимогам фахової підготовки майбутніх соціальних працівників i потребує цілеспрямованої роботи під час формувального етапу експерименту 3 метою підвищення рівнів професійної, комунікативно-мовленнєвої компетентності в закладах вищої освіти.

3 огляду на зазначене, перспективу подальших наукових розвідок убачаємо в розробленні експериментальної методики формування комунікативно-мовленнєвої компетентності майбутніх соціальних працівників у процесі фахової підготовки. 


\section{ЛІТЕРАТУРА}

Лега, Ю. Г. (2003). Концептуальні засади підготовки менеджерів вищої кваліфрікації. Черкаси: чдту (Leha, Yu. H. (2003). The conceptual bases of training of managers of higher qualification. Cherkasy: ChDTU).

Браже, Т. Г. (1995). Современная аттестация учителей: цели и тенденции. Педагогика, 3, 69 (Brazhe, T. H. (1995). The modern certification of teachers: goals and trends. Pedagogics, 3, 69).

Розенталь, М., Юдина, П. (1968). Философский словарь. Москва: Политиздат (Rozental, M., Yudina, P. (1968). The philosophical dictionary. M oscow: Politizdat).

Словник української мови. Академічний тлумачний словник (1970-1980) http://sum.in.ua/s/pokaznyk (Dictionary of the Ukrainian language (1970-1980) Academic Interpretative Dictionary) Retrieved from: http://sum.in.ua/s/pokaznyk).

Бусел, В. Т. (Ред.) (2005). Великий тлумачний словник української мови. (Busel, V. T. (Ed.). (2005). Great Dictionary of the M odern Ukrainian Language. Kyiv: Irpin, VTF «Perun»).

Новиков, А. М. (2010). Методология научного исследования (Novikov, A. М. (2010). The research methodology).

Ожегов С. И. (1986). Словарь русского язика: около 57000 слов. Режим доступа: http://cyberlan.com.ua/wp-content/uploads/2015/07/Tolkovij-slovarj-russkogoyazika.pdf (The Russian language dictionary: About 57,000 words). Retrieved from: http://cyberlan.com.ua/wp-content/uploads/2015/07/Tolkovij-slovarj-russkogoyazika.pdf).

Попович, М. В. (2006). Універсальний словник-енциклопедія. Київ: Вид-во «ТЕКА» (Popovych, M. V. (2006). The universal encyclopedia dictionary. Kyiv: "TEKA").

\section{PEЗЮME}

Березовская Людмила. Уровни сформированности коммуникативно-речевой компетентности будущих социальных работников в процессе профессиональной подготовки.

В статье осуществлен анализ уровней сформированности коммуникативноречевой компетентности будущих сочиальных работников в прочессе профессиональной подготовки. Определен диагностический инструментарий, критерии, показатели и уровни коммуникативно-речевой компетентности будущих социальных работников. Полученные в ходе эксперимента результаты свидетельствуют о том, что студенты экспериментальной и контрольной групп демонстрируют в большинстве удовлетворительный и низкий уровни срормированности коммуникативно-речевой компетентности, что не соответствует требованиям профессиональной подготовки будущих социальных работников и требует целенаправленной работы во время формирующего этапа эксперимента с целью повышения уровней профессиональной, коммуникативноречевой компетентности в учреждениях высшего образования.

Ключевые слова: уровни сформированности, коммуникативно-речевая компетентность, показатели, критерии, будущие социальные работники.

\section{SUM MARY}

Berezovska Liudmyla. Levels of formation of communicative-speaking competence of future social workers in the professional training process.

The effectiveness of training of a specialist - the future social worker depends on many factors. Firstly, it is the level of formation of communicative-speaking competence, as a component of professional development of a social worker. 
Under the formation of communicative-speaking competence of the future social worker, we understand a complex concept. It includes: personal component, that is maturity of personal qualities, first of all, such as professional values and motives, empathy, tolerance, humanity. Professional component, which includes mastering a future employee of the whole complex of special knowledge, skills, professionalactions. Knowledge of the conceptual terminological apparatus of communicative-speaking competence, ability to analyze a communicative situation, to design and analyze it, to exercise reflection and self-esteem. In addition, it includes individual style of communication, as well as activity of the person, providing realization of the gained experience in communicative-speaking activity and further professional improvement.

Based on defined criteria there were selected appropriate tasks, questionnaires and methods in order to identify the levels of communication skills of future social workers.

Indicators, which are developed for each criterion, take into account the amount of knowledge acquired by students during previous years of higher education, the practical skills and skills that allow them to characterize their behavior in situations relevant to the future profession, as well as reflect the persistence of the identified.

High-quality analysis of the results of the development of communicative-speaking competence in the students of the experimental and control groups showed in the majority of satisfactory and low levels. That do not meet the requirements of professional training of future social workers and indicates the need for purposeful work with students in order to improve their communicative-speaking competence in higher education.

Key words levels of formation, communicative-speaking speech competence, indicators, criteria, future social workers.

Удк 37.011.3:372.461

Вікторія Будянська

Харківський національний економічний університет

імені Семена Кузнеця

ORCID ID 0000-0003-0621-4571

Галина Мариківська

Харківський національний університет внутрішніх справ

ORCID ID 0000-0001-9561-9292

DOI 10.24139/2312-5993/2019.07/172-184

\title{
УДОСКОНАЛЕННЯ ОРАТОРСЬКОЇ МАЙСТЕРНОСТІ МАЙБУТНІХ ПРАВОЗАХИСНИКІВ НА ЗАНЯТТЯХ З УКРАЇНСЬКОЇ МОВИ ПРОФЕСІЙНОГО СПРЯМУВАННЯ В ЗАКЛАДАХ ВИЩОЇ ОСВІТИ
}

\begin{abstract}
Метою статті $\epsilon$ показ шляхів удосконалення ораторської майстерності майбутніх правозахисників у закладах вищої освіти. Було застосовано такі методи дослідження: порівняльно-зіставний, поняттєво-термінологічний аналіз, систематизація та узагальнення. Реалізація завдання розвитку красномовності майбутніх правозахисників має передбачати розкриття студентам сутності цього поняття, що сприятиме підвищенню інтересу до чієї проблеми й активізації зусиль студентів у цьому напрямі. Перспективним напрямом нашого дослідження ми вважаємо розробку вправ і завдань для студентів будь-якого профрілю навчання (зокрема правозахисників), а також для викладачів закладів вищої освіти для вдосконалення їхньої красномовності.
\end{abstract}

